\title{
PENYIMPANGAN SEKSUAL: SEBUAH INTERPRETASI TEOLOGI, PSIKOLOGI DAN PENDIDIKAN ISLAM
}

\author{
MASMURI \\ Dosen Sekolah Tinggi Ilmu Kesehatan (STIKES) \\ Yayasan Rumah Sakit Islam (YARSI) Pontianak \\ murissambas@yahoo.co.id \\ SYAMSUL KURNIAWAN \\ Dosen Fakultas Tarbiyah dan Ilmu Keguruan (FTIK) \\ Institut Agama Islam Negeri (IAIN) Pontianak \\ syamsul kurniawan@yahoo.com
}

\begin{abstract}
Sexual deviance, sexual abnormality, or sexual violence is behavioral force to gain a sexual pleasure from sexual objects or in a peculiar way. In this context, the sexual deviance is clearly against the bumanity and the common sense. This issue would be discussed thoroughly by the writers. Besides, the main focus of this writing is the sexual deviance which is limited by theological, psychological, and Islamic education interpretation.
\end{abstract}

Keywords: Sexual Deviance, Sex Education

\section{PENDAHULUAN}

Pada diri manusia terdapat dorongan seksual. Dorongan seksual ini tidak hanya karunia atau rahmat dari Allah Swt, melainkan juga amanah yang harus dijaga. Maksudnya, agama (terutama Islam) menghendaki agar dorongan seksual ini dapat bersesuaian dengan fitrah kemanusiaan dan akal sehat, dalam artian tersalurkan pada dan dengan cara yang benar.

Dorongan seksual adalah sebuah fitrah kemanusiaan, tentu keinginan untuk menurutinya merupakan suatu hal yang kodrati dan sejalan dengan maksud normatif agama. Agama hanya melarang jika dorongan seksual itu mengarah pada hubungan seksual yang menyimpang dari fitrah kemanusiaan dan akal sehat, atau mengarah pada yang kita sebut penyimpangan seksual (sexual deviation). Hal ini karena menurut ajaran agama, hubungan seksual bukan sekedar cara untuk menuruti dorongan seksual atau jalan memperoleh kepuasan seksual, tetapi lebih dalam maknanya dari itu berkaitan dengan kebutuhan manusia untuk berkembang biak.

Meski jelas-jelas menyalahi ajaran agama, senyatanya tidak sedikit pula orang yang terindikasi melakukan penyimpangan seksual. Seperti santer atau marak dibicarakan belakangan ini di tanah air perihal kelompok-kelompok yang mengatasnamakan Hak Asasi Manusia (HAM) untuk melegitimasi keberadaan Lesbian, Gay, Biseksual, dan Trans-Gender (LGBT). Kecuali itu pula, ada kasus pemerkosaan yang selanjutnya berujung pada pembunuhan korban, seperti kasus pemerkosaaan yang menimpa Yuyun (14 tahun) oleh 14 anak baru gede (ABG) di Bengkulu (http://regional.liputan6.com/read/2499720/kronologi-kasus-kematian-yuyun-di-tangan-14-abg-

bengkulu). Atau pemerkosaan yang menimpa Eno F. (19 tahun), yang juga berujung pada kematiannya secara menggenaskan (https: // m. tempo. Co / read / news / 2016 / 05/17/064771733 / kasusgagang-pacul-usia-enno-farihah-ternyata-19-tahun). 
Fokus tulisan ini adalah perilaku seksual menyimpang, yang ingin penulis lihat dari perspektif teologis, psikologi, dan pendidikan. Beberapa tulisan yang juga mengkaji tema serupa, seperti tulisan Ramlan Yusuf Rangkuti yang berjudul "Homo Seksual dalam Perspektif Hukum Islam" (Jurnal AsySyir'ah, Volume 46, Nomor 1, Januari-Juni 2012) dan tulisan Agus Salim Nasution yang berjudul "Homo Seksual dalam Pandangan Hukum Islam" (Jurnal Ushuluddin, Voume 21, Nomor 1, Januari 2014). Kedua tulisan tersebut, mengulas pandangan hukum Islam tentang homo seksual yang dikaji berdasarkan perspektif hukum Islam. Kedua penulis juga sependapat, bahwa homo seksual haram menurut hukum Islam. Keduanya juga mengungkapkan bahwa para ulama berbeda pendapat soal sanksi hukum yang dapat diberikan pada pelaku. Kecuali tulisan ini, ada tulisan Yogestri Raleh Mahapir dan Adhyatman Prabowo tentang "Kecemasan Sosial Kaum Homo Seksual, Gay, dan Lesbian” (Jurnal Ilmiah Psikologi Terapan, Volume 2, Nomor 22, Januari 2014). Tulisan Yogestri Raleh Mahapir dan Adhyatman Prabowo ini mengulas tentang perbedaan tingkat kecemasan sosial yang ada pada individu homoseksual gay dan lesbian.

Tulisan ini berjudul "Penyimpangan Seksual: Sebuah Interpretasi Teologi, Psikologi dan Pendidikan Islam.” Pada konteks ini, tulisan ini sama-sama mengulas tentang penyimpangan seksual. Bedanya, tulisan ini melihat penyimpangan seksual tidak sebatas pada homo seksual sebagaimana ketiga kajian di atas, melainkan diulas secara umum. Hal lainnya tulisan ini dikaji berdasarkan interpretasi yang holistik terutama dari sudut pandang teologis, psikologi, dan pendidikan Islam.

Secara metodologis, tulisan ini tergolong kajian kualitatif, yang menurut Satori dan Komariah (2013: 24) dirancang agar hasil kajian mempunyai kontribusi terhadap teori. Kajian ini juga tergolong kajian kepustakaan oleh karena menitikberatkan pada analisis atau interpretasi bahan tertulis berdasarkan konteksnya. Sebagaimana Prastowo (2011: 190-191), kajian kepustakaan adalah kajian yang bersinggungan dengan kepustakaan dan sejenisnya. Sementara metode yang digunakan adalah metode deskriptif, yang dalam hal ini dianggap relevan untuk menuturkan, memaparkan, menganalisis, menginterpretasikan berbagai informasi kepustakaan yang diperoleh. Setelah informasi kepustakaan terkumpul, yaitu yang berhubungan dengan penyimpangan seksual dalam interpretasi teologis, psikologi, dan pendidikan, baru kemudian informasi kepustakaan tersebut diolah dan disesuaikan dengan kebutuhan analisis (Suyanto dan Sutinah 2006: 56).

\section{GAMBARAN UMUM TENTANG PENYIMPANGAN SEKSUAL}

Manusia tidak selamanya atau semuanya berperilaku normal. Beberapa di antaranya ada yang memiliki kecenderungan berperilaku menyimpang. Salah satu contohnya adalah perilaku seksual menyimpang.

Penyimpangan seksual (sexual deviation) atau abnormalitas seksual (sexual abnormality) atau ketidakwajaran seksual (sexual perversion) atau kejahatan seksual (sexual harrasment) adalah bentuk dorongan dan kepuasan seksual yang diperoleh atau ditunjukkan kepada objek seksual secara tidak lazim (Abdullah, http://www.diffy.com/cmm/artikel/definisi.penyimpangan1.html). Disebut tidak lazim karena perilaku menyimpang seksual diikuti oleh fantasi seksual yang diorientasikan pada pencapaian orgasme melalui hubungan di luar hubungan kelamin heteroseksual dengan jenis kelamin yang sama atau dari partner seks di bawah umur atau hubungan seksual yang secara normatif bertentangan dengan norma-norma tingkah laku seksual yang diakui masyarakat secara umum (Junaedi, 2010). Hal inilah yang mendasari asumsi, penyimpangan seksual sebagai bentuk penyalahgunaan fitrah kemanusiaan dan bertentangan dengan akal sehat.

Macam-macam penyimpangan seksual di antaranya bisa dilihat pada tabel 1 di bawah ini: 
TABEL 1

MACAM-MACAM PENYIMPANGAN SEKSUAL

\begin{tabular}{|c|c|c|}
\hline No & $\begin{array}{c}\text { Macam Penyimpangan } \\
\text { Seksual }\end{array}$ & Keterangan \\
\hline 1 & Fetishisme & $\begin{array}{l}\text { Perilaku seks menyimpang di mana kepuasan seksnya } \\
\text { diperoleh dengan cara onani atau masturbasi dengan benda- } \\
\text { benda mati seperti celana dalam, bh, gaun, dan semacamnya. }\end{array}$ \\
\hline 2 & Homo Seksual & $\begin{array}{l}\text { Kelainan di mana seseorang menyukai berhubungan seksual } \\
\text { dengan sesama jenis. Pada laki-laki disebut gay dan pada } \\
\text { perempuan disebut lesbian. }\end{array}$ \\
\hline 3 & Sadomasokisme & $\begin{array}{l}\text { Penyimpangan seksual di mana seseorang merasakan } \\
\text { memperoleh kenikmatan seksual setelah menyakiti pasangan } \\
\text { seksnya. }\end{array}$ \\
\hline 4 & Masokisme & $\begin{array}{l}\text { Kelainan seks di mana seseorang menikmati seks setelah } \\
\text { terlebih dulu disiksa oleh pasangannya. }\end{array}$ \\
\hline 5 & Voyeurisme & $\begin{array}{l}\text { Perilaku menyimpang seksual di mana seseorang } \\
\text { memperoleh kepuasan seksual setelah mengintip orang lain } \\
\text { yang sedang melakukan hubungan seksual, sedang telanjang, } \\
\text { sedang mandi, dan semacamnya. }\end{array}$ \\
\hline 6 & Pedofilia & $\begin{array}{l}\text { Orang dewasa yang menyukai berhubungan seksual dengan } \\
\text { anak yang berusia di bawah umur. }\end{array}$ \\
\hline 7 & Bestially & $\begin{array}{l}\text { Kelainan seksual di mana seseorang menyukai berhubungan } \\
\text { seksual dengan binatang seperti anjing, kuda, kambing, ayam, } \\
\text { dan lain-lain. }\end{array}$ \\
\hline 8 & Incest & $\begin{array}{l}\text { Seseorang yang berhubungan seks dengan sesama anggota } \\
\text { keluarga (sedarah). }\end{array}$ \\
\hline 9 & Necrophilia & $\begin{array}{l}\text { Kelainan seksual di mana seseorang menyukai berhubungan } \\
\text { seksual dengan mayat. }\end{array}$ \\
\hline 10 & Zoophilia & $\begin{array}{l}\text { Kelainan seksual di mana seseorang merasa terangsang } \\
\text { setelah melihat binatang sedang berhubungan seks. }\end{array}$ \\
\hline 11 & Sodomi & $\begin{array}{l}\text { Kelainan seksual di mana seorang laki-laki menyukai } \\
\text { hubungan seks melalui dubur pasangannya. }\end{array}$ \\
\hline 12 & Frotteurisme & $\begin{array}{l}\text { Kelainan seksual di mana seseorang laki-laki merasa } \\
\text { memperoleh kepuasan seksual dengan jalan menggesek- } \\
\text { gesekkan alat kelaminnya ke tubuh perempuan di tempat } \\
\text { publik/umum seperti di bis, kereta, dan semacamnya. }\end{array}$ \\
\hline
\end{tabular}

Sumber: Sarwono, 2002.

Demikianlah macam-macam penyimpangan seksual sebagaimana ditunjukkan pada tabel 1 di atas. Betul, bahwa tidak semua negara atau komunitas masyarakat melarang sejumlah perilaku seksual menyimpang. Beberapa negara atau komunitas masyarakat justru ada yang melegalkannya. Sementara 
sebagian lain melarangnya. Seperti perkawinan sejenis yang dianggap legal di 13 negara bagian di Amerika Serikat, yaitu di di Connecticut, Iowa, Massachussets, Orgeon, New Hampshire, Newyork, Vermont, Maryland, Hawaii, Maine, dan Washington DC. Atau yang juga legal di Belanda, Belgia, Spanyol, Kanada, Afrika Selatan, Norwegia, Swedia, Portugal, Meksiko, Islandia, Argentina, Uruguay, Selandia Baru, Perancis, Denmark, Inggris, Wales, Skotlandia, Brazil, Luxemburk, Finlandia, Irlandia, dan selanjutnya Vietnam. Sementara Malaysia, Brunei, dan juga Indonesia (yang ada di Asia) jelas melarang hal tersebut (Sindo, http://lifestyle.sindonews.com/read/1082855/166/daftar-negara-yangmelegalkan-pernikahan-sejenis-dan-lgbt-145494358).

Sepantasnyalah penyimpangan seksual mengalami penolakan di masyarakat. Hal ini lebih karena resiko yang dapat muncul dari perilaku seksual menyimpang. Beberapa di antaranya dipaparkan di bawah ini:

1. Seks bebas yang dilakukan pasangan tanpa ikatan pernikahan dan dengan tidak menggunakan alat kontrasepsi menjadi sebab kehamilan pranikah. Akibatnya, banyak di antara perempuan yang hamil pranikah yang melakukan aborsi atau pengguguran kandungan, dengan cara bantuan ramuan atau obat-obatan, memijat peranakannya dengan bantuan dukun atau dokter atau bidan, dan lain sebagainya, yang jelas beresiko pada pendarahan, infeksi, bahkan kematian si calon ibu.

2. Aktifitas seks yang tidak sehat sangat beresiko terhadap munculnya penyakit menular seksual. Beberapa di antaranya dapat dilihat pada tabel 2 sebagai berikut:

TABEL 2

PENYAKIT MENULAR SEKSUAL

\begin{tabular}{|c|l|l|}
\hline No & \multicolumn{1}{|c|}{ Penyakit } & \multicolumn{1}{c|}{ Keterangan } \\
\hline 1 & Gonorea & $\begin{array}{l}\text { Seseorang yang menderita penyakit ini kencingnya bernanah. } \\
\text { Penyakit ini menyerang organ seks dan organ kemih. Kecuali itu, } \\
\text { juga menyerang selaput lendir mulut, mata, anus, dan beberapa } \\
\text { organ tubuh lainnya. Bakteri yangmenjadi penyebab penyakit ini } \\
\text { adalah Gonococcus. }\end{array}$ \\
\hline 2 & Siflis & $\begin{array}{l}\text { Disebut juga dengan "Raja Singa". Penyakit ini ditularkan melalui } \\
\text { hubungan seksual atau penggunaan barang-barang seperti handuk, } \\
\text { celana dalam, jarum suntik, dan lain-lain dari seorang yang tertular. } \\
\text { Penyebab penyakit ini adalah kuman Treponema Pallidum. }\end{array}$ \\
\hline 3 & Herpes & $\begin{array}{l}\text { Penyebabnya adalah virus Harpes Simpleks. Disebut-sebut } \\
\text { penyakit yang telah dikenal sejak lama dalam sejarah umat manusia. } \\
\text { Ditularkan oleh Bangsa Yunani dan Romawi, terutama oleh Louis } \\
\text { XV. }\end{array}$ \\
\hline 4 & Klamidia & $\begin{array}{l}\text { Klamidia berasal dari kata Chlamydia, sejenis organisme } \\
\text { mikroskopok yang dapat mengakibatkan infeksi pada leher rahim, } \\
\text { rahim, saluran indung telur, dan saluran kencing. Gejala yang } \\
\text { banyak dijumpai yaitu keluarnya cairan dari vagina yang berwarna } \\
\text { kuning dan disertai rasa panas/ terbakar saat kencing. }\end{array}$ \\
\hline 5 & Candida & $\begin{array}{l}\text { Disebut pula infeksi ragi. Di dalam vagina perempuan terdapat } \\
\text { berjuta-juta ragi. Tidak akan menjadi masalah jika volumenya }\end{array}$ \\
\hline
\end{tabular}




\begin{tabular}{|c|l|l|}
\hline & & $\begin{array}{l}\text { normal. Namun, jika ragi berkembang terlalu pesat, dalam keadaan } \\
\text { tertentu dapat menjadi infeksi. }\end{array}$ \\
\hline 6 & Chancroid & $\begin{array}{l}\text { Disebabkan sejenis bakteri yang menyerang kulit kelamin dan } \\
\text { menyebabkan luka kecil bernanah. Jika luka ini pecah, bakteri akan } \\
\text { menjalar ke daerah kelamin. }\end{array}$ \\
\hline 7 & $\begin{array}{l}\text { Glanuloma } \\
\text { Inguinale }\end{array}$ & $\begin{array}{l}\text { Mirip dengan Chancroid. Ebabnya juga karena bakteri. Bagian yang } \\
\text { diserang penyakit adalah permukaan kulit penis, bibir vagina, } \\
\text { klitoris, anus, dan akan berubah membentuk jaringan berisi cairan } \\
\text { yang mengeluarkan bau busuk. }\end{array}$ \\
\hline 8 & $\begin{array}{l}\text { Lymphogranuloma } \\
\text { venereum }\end{array}$ & $\begin{array}{l}\text { Disingkat LGV. Penyebabnya adalah virus dan dapat } \\
\text { mempengaruhi seluruh organ tubuh, Disebut-sebut berbahaya } \\
\text { karena antibiotik belum mampu menanggulanginya. }\end{array}$ \\
\hline 10 & ARC & $\begin{array}{l}\text { Adalah singkatan dari Acquired Immuno Deficiency Syndrome, } \\
\text { yaitu menurunnya sistem kekebalan tubuh seseorang. Penyebabnya } \\
\text { adalah virus yang disebut HIV (human immunodeficiency virus). }\end{array}$ \\
\hline 12 & PID & $\begin{array}{l}\text { Singkatan dari AIDS related complex, yang menyebabkan } \\
\text { timbulnya pembengkakan pada kelenjar di sekitar paha dan daerah } \\
\text { lainnya. }\end{array}$ \\
\hline 11 & Scabies & $\begin{array}{l}\text { Penyakit yang disebabkan serangga yang disebut mite. Serangga } \\
\text { tersebut dapat menelusup masuk melalui kelamin dan berkembang } \\
\text { biak dengan cepat. }\end{array}$ \\
\hline $\begin{array}{l}\text { Singkatan dari Pelvis Inflammatory Disease, yaitu penyakit infeksi } \\
\text { sistem saluran reproduksi perempuan seperti gonorea atau } \\
\text { clamydia. }\end{array}$ \\
\hline $\begin{array}{l}\text { Penyakit ini merupakan penyakit yang menyerang vagina } \\
\text { perempuan dan menyebabkan terjadinya infeksi dengan } \\
\text { mengeluarkan cairan busa disertai dengan rasa gatal dan panas pada } \\
\text { vagina. }\end{array}$ \\
\hline $\begin{array}{l}\text { Penyakit yang disebabkan oleh virus yang menyerang alat kelamin } \\
\text { seseorang. Pada laki-laki virus ini menyerang bagian kepala penis, } \\
\text { dan sementara pada perempuan menyerang bibir vagina dan daerah } \\
\text { sekitar anus. }\end{array}$ \\
\hline 13
\end{tabular}

Sumber: Junaedi, 2010 dan Dianawati, 2006.

\section{PENYIMPANGAN SEKSUAL DALAM PERSPEKTIF TEOLOGIS}

Hakikatnya, laki-laki dan perempuan terlahir dengan membawa sejumlah perbedaan mendasar. Perbedaan tersebut tidak seharusnya menjadi argumentasi untuk merendahkan satu dengan yang lain, melainkan untuk mengenali fungsi dan selanjutnya saling melengkapi satu dengan yang lain. Hal ini diisyaratkan dalam QS al-Hujurat ayat 13. 


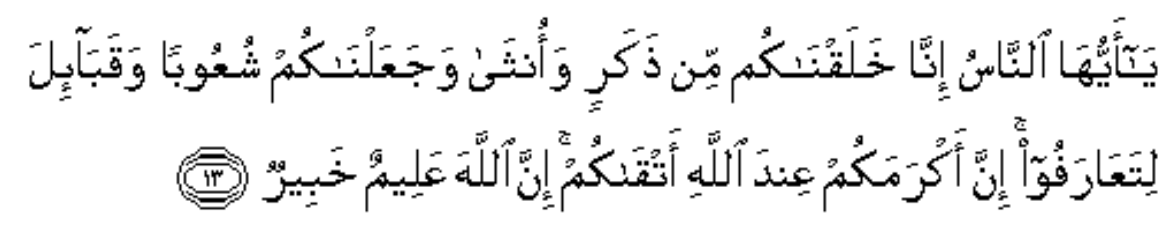

Hai manusia, Sesungguhnya kami menciptakan kamu dari seorang laki-laki dan seorang perempuan dan menjadikan kamu berbangsa-bangsa dan bersuku-suku supaya kamu saling kenalmengenal. Sesungguhnya orang yang paling mulia di antara kamu di sisi Allah ialah orang yang paling takwa di antara kamu. Sesungguhnya Allah Maha Mengetahui lagi Maha Mengenal.

Menyadari perbedaan yang fitrah ini, Islam memberikan aturan atau norma-norma, agar masingmasing fitrah terpelihara dan saling melengkapi. Islam menghendaki agar laki-laki berkepribadian maskulin dan perempuan berkepribadian feminim. Dengan demikian, secara teologis tidak seharusnya laki-laki menyerupai perempuan dan sebaliknya perempuan menyerupai laki-laki dalam sudut penampilan maupun perilaku.

Kecuali diciptakan dengan sejumlah perbedaan, baik fisik maupun fungsional, Allah SWT telah menanamkan pada setiap orang potensi berkembang biak berupa dorongan untuk berhubungan seksual. Dalam QS al-A'raf ayat 31-33, Allah SWT menyeru pada manusia agar bersikap sewajarnya (baca: tidak berlebih-lebihan atau tidak melampaui batas) dalam memperoleh dan menikmati kenikmatan dunia apalagi berlaku keji untuk hal tersebut.

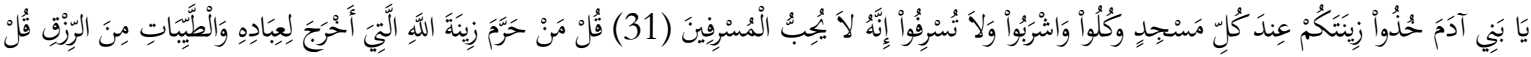

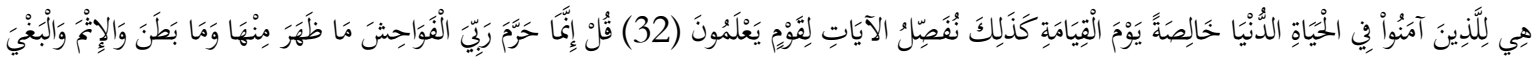

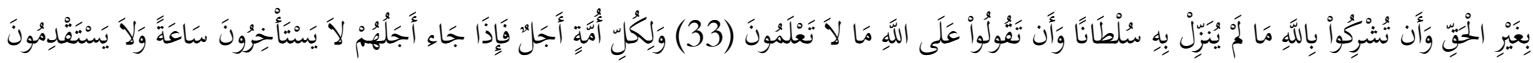

Kaitannya dengan pemenuhan kebutuhan dorongan seksualnya, secara teologis Islam melegalkannya melalui pernikahan, antara seorang laki-laki dan seorang perempuan yang halal menurut ketentuan agama. Melalui pernikahan, hubungan seksual menjadi halal dan bahkan bernilai ibadah. Dalam Alquran disebutkan pada banyak ayat tentang urgensitas menikah.

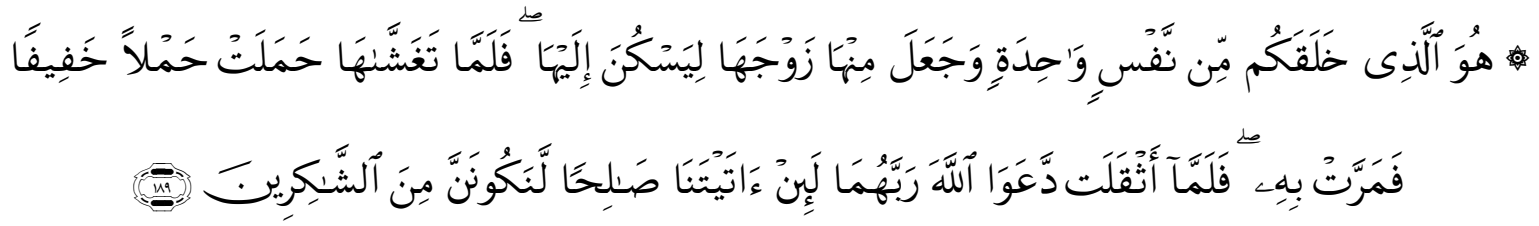


Dialah yang menciptakan kamu dari diri yang satu dan dari padanya dia menciptakan isterinya, agar dia merasa senang kepadanya. Maka setelah dicampurinya, isterinya itu mengandung kandungan yang ringan, dan teruslah dia merasa ringan (beberapa waktu). Kemudian tatkala dia merasa berat, keduanya (suami-isteri) bermohon kepada Allah, Tuhannya seraya berkata: "Sesunggubnya jikea Engkau memberi kami anak yang saleh, tentulah kami terraasuk orang-orang yang bersyukur".

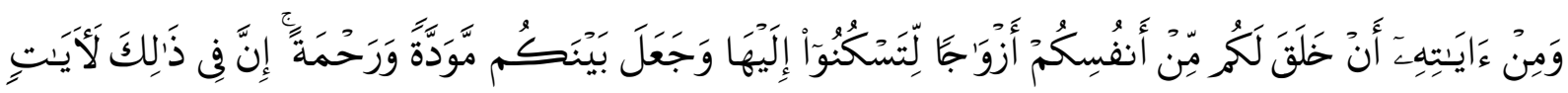

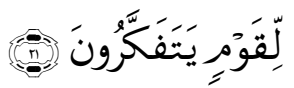

Dan di antara tanda-tanda kelkuasaan-Nya ialah dia menciptakan untukmu isteri-isteri darijenismu sendiri, supaya kamu cenderung dan merasa tenteram kepadanya, dan dijadikan-Nya di antaramu rasa kasib dan sayang. Sesunggubnya pada yang demikian itu benar-benar terdapat tanda-tanda bagi kaum yang berfikir.

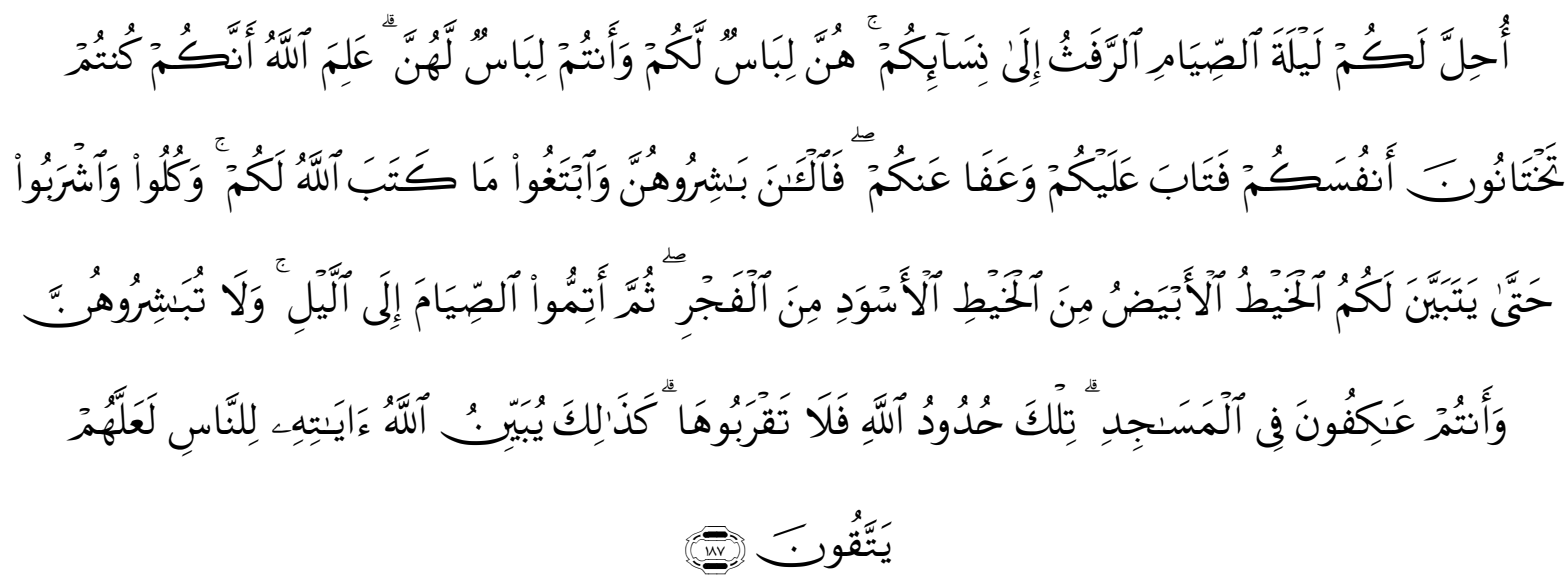

Dihalalkan bagi kamu pada malam hari bulan puasa bercampur dengan isteri-isteri kamu; mereka adalah pakaian bagimu, dan kamupun adalah pakaian bagi mereka. Allah mengetahui babwasanya kamu tidak dapat menahan nafsumu, Karena itu Allah mengampuni kamu dan memberi maaf kepadamu. Maka sekarang campurilah mereka dan ikutilah apa yang telah ditetapkan Allah untukmu, dan makan minumlah bingga terang bagimu benang putih dari benang hitam, yaitu fajar. Kemudian sempurnakanlah puasa itu sampai (datang) malam, (tetapi) janganlah kamu campuri mereka itu, sedang kamu beri'tikaf dalam mesjid. Itulah larangan Allah, maka janganlah kamu mendekatinya. Demikianlah Allah menerangkan ayat-ayat-Nya kepada manusia, supaya mereka bertakwa.

Sebaliknya, secara teologis, Islam melarang bentuk-bentuk penyimpangan seksual. Fetishisme misalnya. Sebagaimana telah diulas di atas bahwa fetishisme yaitu penyimpangan seksual di mana kepuasan seksnya diperoleh dengan cara onani atau masturbasi dengan benda-benda mati seperti celana dalam, bh, gaun, dan semacamnya. Mazhab Syafici dan Maliki mengharamkannya. Menurut mazhab Syafici onani atau masturbasi digolongkan pebuatan yang melampaui batas sebagaimana disebutkan Allah Swt dalam QS al-Mukminun ayat 7 dan QS al-Maarij ayat 31. Bagi yang bergejolak dorongan seksualnya sementara mampu menikah, maka hendaknya bersabar dan tetap menjaga kesuciannya.

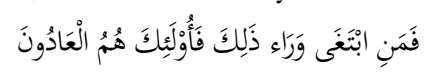

Barangsiapa mencari yang di balik itu, maka mereka Itulab orang-orang yang melampaui batas. 


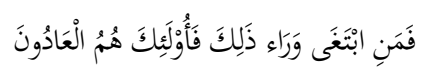

Barangsiapa mencari yang di balik itu, maka mereka Itulah orang-orang yang melampaui batas.

Kecuali itu, Islam juga melarang berzinah atau berhubungan seksual di luar akad nikah. Bentuknya bisa karena suka sama suka atau karena memperkosa dan atau karena melacur. Berdasarkan QS al-Isra' ayat 32, perbuatan zina tergolong perbuatan keji dan jalan yang buruk.

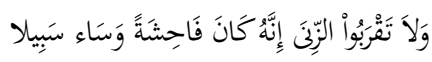

Dan janganlah kamu mendekati zina; Sesunggubnya zina itu adalah suatu perbuatan yang keji. dan suatu jalan yang buruk.

Apalagi, jikalau yang dizinahi adalah perempuan yang mempunyai hubungan darah seperti ibu kandung atau anak kandung, kecuali berdosa, hukumannya lebih berat lagi. Rasulullah Saw bersabda: "Barangsiapa menzinahi mahramnya maka bunuhlah" (HR al-Hakim). Hal ini juga sesuai dengan QS An-Nisa ayat 22.

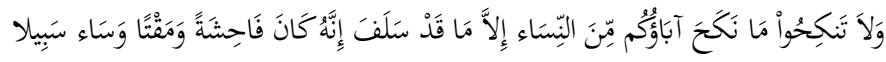

Dan janganlah kamu kawini wanita-wanita yang telah dikawini oleh ayahmu, terkecuali pada masa yang Telah lampau. Sesunggubnya perbuatan itu amat keji dan dibenci Allah dan seburuk-buruk jalan (yang ditempub).

Ibn Mas'ud bertanya pada Rasulullah Saw.: "Dosa apakah yang paling berat di sisi Allah Swt? Beliau menjawab: "Kamu menjadi sekutu bagi Allah padahal Dialah yang menciptakan kamu". Dia bertanya lagi: "Kemudian apa?”. Beliau menjawab: "Kamu membunuh puteramu karena kamu takut ia makan bersamamu." Dia berkata lagi: "Kemudian apa?”. Beliau menjawab: "kamu berzina dengan isteri tetanggamu. Maka Allah menurunkan ayat 68-70 dari surah al-Furqan.

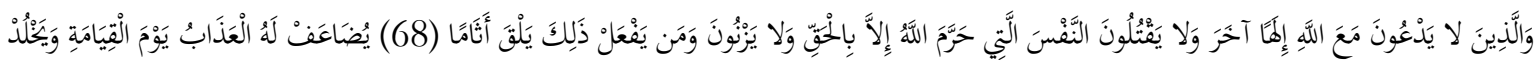

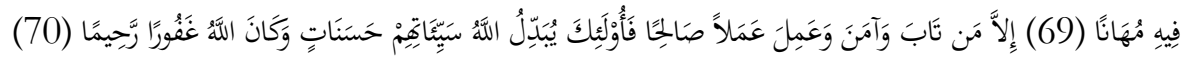

Dan orang-orang yang tidak menyembah Tuhan yang lain beserta Allah dan tidak membunuh jiwa yang diharamkan Allah (membunubnya) kecuali dengan (alasan) yang benar, dan tidak berivina, barang siapa yang melakukan yang demikian itu, niscaya dia mendapat (pembalasan) dosa(nya), (yakni) akan dilipat gandakan azab untuknya pada hari kiamat dan dia akan kekeal dalam azab itu, dalam keadaan terbina. Kecuali orang-orang yang bertaubat, beriman dan mengerjakan amal saleb; Maka itu kejahatan mereka diganti Allah dengan kebajikan. dan adalah Allah Maha Pengampun lagi Maha Penyayang.

Berdasarkan ayat ini, zina sejajar dengan syirik dan membunuh anak sendiri (Azhar, 2006: 8992 dan Ibn Qayyim, 2000: 3-4).

Demikian pula penyimpangan seksual homo seksual dan lesbian, keduanya merupakan perbuatan yang diharamkan dan dimurkai Allah Swt. Pelajaran bisa dipetik dari kam Nabi Luth as. yang bermukim di daerah Sadum Paletina. Sebagaimana dijelaskan pada QS al-A'raf ayat 80-81, kaum Nabi Luth dihujani Allah dengan batu akibat pebuatan seksual menyimpang mereka. Nabi Muhammad Saw sendiri juga melaknat kaum homo seksual. Dalam hal ini, Nabi bersabda: "Semoga Allah Swt melaknat seorang yang berani melakukan perbuatan kaum Luth." Beliau mengulang-ulang hingga tiga kali (HR Ahmad). Dalam hadits lain, Nabi Muhammad Saw bersabda: "Sesungguhnya suatu hal yang amat ku takuti terhadap umatku adalah pekerjaan yang dilakukan oleh kaum Nabi Luth" (HR Ibn Majah dan Turmudzi). 
Dalam QS al-Mu'minun ayat 1-7, secara tegas Allah Swt mengingatkan tentang pentingnya menjauhi perilaku seksual menyimpang, oleh karena perbuatan tersebut tergolong perbuatan zina yang mana termasuk dosa besar yang harus dijauhi seorang muslim karena keji dan kotor serta merupakan cara pemuasan seksual yang paling buruk. Pelakunya disebut-sebut sebagai orang yang merugi, tercela dan melampaui batas.

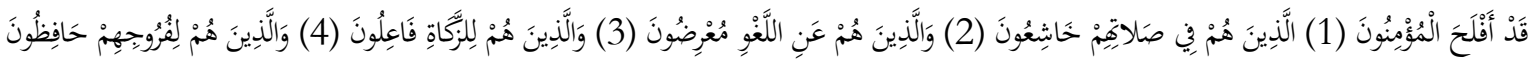

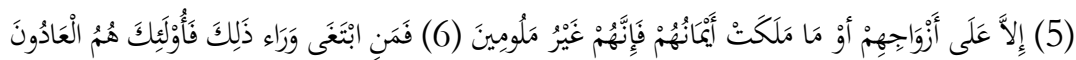

Sesunggubnya beruntunglab orang-orang yang beriman, (yaitu) orang-orang yang kbusyu' dalam sembabyangnya, dan orang-orang yang menjaubkan diri dari (perbuatan dan perkataan) yang tiada berguna, dan orang-orang yang menunaikan zakat, dan orang-orang yang menjaga kemaluannya. Kecuali terhadap isteri-isteri mereka atau budak yang mereka miliki. Maka sesungguhnya mereka dalam hal ini tiada tercela. Barangsiapa mencari yang di balik itu, maka mereka itulah orang-orang yang melampaui batas.

Kecuali itu Ibn Qayyim (2000: 1-2) mengatakan bahwa penyelewengan seksual dalam konteks ini merusak kesucian dan kehormatan diri, merusak nasab, memperbanyak kejahatan, merusak hubungan kekeluargaan, merusak tatanan kehidupan, merusak peradaban, dan mendatangkan murka Allah Swt di dunia dan di akhirat. Telah diulas juga sebelumnya tentang dampak-dampak perilaku seksual menyimpang yang di antaranya menjadi sebab terkena penyakit seperti AIDS dan jenis penyakitpenyakit lainnya.

\section{PENYIMPANGAN SEKSUAL DALAM PERSPEKTIF PSIKOLOGI DAN PENDIDIKAN ISLAM}

Pola asuh orang tua dan stimulasi yang diberikan oleh lingkungan pada seseorang harus diakui punya peran yang besar dan signifikan terutama dalam memperkuat identitas dan tumbuh kembang psikis seorang anak. Pada konteks ini, pertumbuhan dan perkembangan masa kanak-kanak jelas menjadi masa yang sangat urgen dan signifikan dalam hal pertumbuhan psikologis dan kecenderungan berinteraksi serta bersosialisasi dengan lingkungan sekitarnya. Pada masa ini hendaklah para orangtua memberikan bimbingan dan pengarahan, termasuk di dalamnya problematika dan wawasan seksualitas.

Sekurang-kurangnya ada lima hal yang menjadi alasan pendidikan seksual menjadi penting:

1. Meningkatnya libido seksualitas. Seperti dimafhumi, perubahan-perubahan hormonal seseorang yang punya pengaruh terhadap hasrat atau dorongan seksual (libido seksualitas) pada seseorang misalnya yang menginjak usia remaja. Peningkatan hasrat atau dorongan seksual ini, dalam tingkatan tertentu memerlukan penyaluran dalam bentuk tingkah laku seksual. Pada konteks inilah para orangtua memberikan bimbingan dan pengarahan, termasuk di dalamnya problematika dan wawasan seksualitas.

2. Penundaan usia pernikahan. Sebab adanya penundaan usia pernikahan lebih dikarenakan adanya undang-undang tentang pernikahan yang menetapkan usia minimal boleh menikah atau berbagai norma sosial di masyarakat yang mensyaratkan pasangan yang menikah harus mempunyai pekerjaan, pendidikan, siap mental, dan sebagainya. Maka dimafhumi, manakala usia pernikahan ditunda, meningkatnya libido seksualitas seseorang yang menginjak usia remaja bisa menjadi sebab terjadinya penyimpangan seksual seperti onani, masturbasi, dan tingkah laku menyimpang lainnya. Untuk itu 
bimbingan dan pengarahan, termasuk di dalamnya problematika dan wawasan seksualitas, sebagai sesuatu hal yang penting bagi mereka.

3. Adanya tabu dan larangan. Ditinjau dari kacamata psikoanalisis, perbincangan tentang seks yang dianggap tabu, karena seks dipicu oleh dorongan-dorongan naluri dalam $i d$. Teori ini dikenalkan oleh Freud. Dalam teori Freud, bahwa salah satu bagian terpenting dari suatu organisme adalah sistem saraf yang memiliki karakter sangat peka terhadap apa yang dibutuhkan. Saat seorang manusia lahir, sistem syarafnya hanya sedikit lebih baik dari binatang lain, itulah yang dinamakan $i d$. Id adalah istilah yang diambil dari kata ganti untuk "sesuatu" atau "itu" (the it), atau komponen yang tak sepenuhnya diakui oleh kepribadian. Id biasanya meredam ketegangan dengan cara memuaskan hasrat-hasrat dasar. Pada konteks ini, id berfungsi untuk memperoleh kepuasandan mengejar kesenangan. Sistem syaraf, sebagai $i d$, bertugas menerjemahkan kebutuhan seseorang menjadi daya motivasional yang disebut sebagai nafsu. Contohnya bayi yang baru lahir. Seorang bayi akan belajar mengisap, terlepas dari ada atau tidaknya puting susu untuk ia hisap. Karena $i d$ memotivasinya untuk melakukan hal tersebut demi memperoleh kepuasan. Dalam teori psikoanalisis, id memang tidak mempunyai kontak dengan kenyataan, maka bayi itu tidak menyadari bahwa sebenarnya dengan mengisap jempol tidak akan membantunya bertahan hidup. Ego atau saya adalah satu-satunya wilayah pikiran yang memiliki kontak dengan realita. Kebutuhan lambat laun akan semakin kuat dan bertambah banyak, sedang keinginan-keinginan lain akan datang silih berganti. Di seputar alam sadar ini, selama tahun-tahun pertama kehidupan seorang bayi, sebagian id berubah menjadi ego (aku). Ego menghubungkan organisme dengan realitas dunia melalui alam sadar yang dia tempati, dan dia mencari objek-objek untuk memuaskan keinginan dan nafsu yang dimunculkan id untuk merepresentasikan apa yang dibutuhkan seseorang. Tidak seperti $i d$, ego berfungsi berdasarkan prinsip-prinsip realitas, artinya dia memenuhi kebutuhan organisme berdasarkan objek-objek yang sesuai dan dapat ditemukan dalam kenyataan. Dorongan-dorongan id ini, terutama yang berhubungan dengan seksual dalam beberapa hal dan kesempatan harus bisa dikendalikan karena terkadang bertentangan dengan dorongan moral yang ada dalam super ego, sehingga tidak selalu dapat dimunculkan terutama saat berhadapan dengan orang lain dalam keterbukaan. Ketika ego berusaha membuat id tetap senang, di sisi lain dia juga mengalami hambatan yang ada di dunia nyata. Segala objek dunia nyata yang menghalangi dan mendukungnya inilah yang kemudian menjadi superego (http://septimartiana.blogspot.co.id /2014/01/ psikoanalisis-sigmund.html). Seperti seorang remaja (dan juga banyak orang dewasa) yang pada umumnya tidak mau mengakui aktfitas seksualnya dan sulit diajak berdiskusi tentang seks, lebih dikarenakan sebab tabu atau larangan diseputar itu. Tabu ini mempersulit komunikasi. Sulitnya komunikasi, khususnya dengan orang tua, dapat menjadi sebab seseorang terjebak dalam perilaku seksual menyimpang.

4. Kurangnya keterbukaan informasi tentang seks. Seseorang yang memasuki usia remaja tanpa pengetahuan yang memadai tentang seks dan tambahan lagi berpacaran, mereka ini rentan terhadap perilaku seksual menyimpang, seperti hubungan seks sebelum menikah. Kurangnya keterbukaan informasi tentang seks dapat disebabkan karena orang tua tabu membincangkan persoalan seks dengan anaknya, sementara seorang anak lebih banyak memperoleh informasi itu dari temantemannya.

5. Pergaulan yang makin bebas. Tidak dipungkiri adanya kecenderungan gaya hidup pergaulan bebas saat ini terutama di kota-kota besar. Tanpa adanya bimbingan dan pengarahan, termasuk di dalamnya problematika dan wawasan seksualitas, seorang anak rentan mengikuti gaya hidup yang salah tersebut. 
Berdasarkan ulasan di atas, perilaku seksual menyimpang rentan terjadi pada siapapun, terutama bagi mereka yang kurang memperoleh bimbingan dan pengarahan termasuk pula kurang mempunyai wawasan dalam hal problematika dan wawasan seputar seksualitas. Pengaruh lingkungan menjadi faktor utama penyebab menyimpangnya perilaku seksual seseorang. Karena itu seseorang, terutama anak dan mereka yang baru menginjak usia remaja, kiranya perlu mendapat sosialisasi pengetahuan tentang seks yang benar. Apalagi telah dijelaskan pada bagian sebelumnya, tidak ada larangan - bahkan dianjurkan seseorang memperoleh pengetahuan tentang seks selama mengarah pada sesuatu hal yang positif. Justru pengetahuan tentang seks perlu diberikan sejak dini usia, agar seorang anak atau yang baru menginjak usia remaja memiliki ketercukupan wawasan tentang seks, sehingga memandang dan memanfaatkan kebutuhan seks mereka dengan cara atau jalan yang positif.

Dalam perspektif pendidikan Islam, seksual perlu diajarkan dan dididikkan dengan benar. Pada konteks ini, pendidikan seksual adalah sosialisasi informasi tentang persoalan seksualitas secara jelas dan benar, yang mencakup proses terjadinya pembuahan, kehamilan, kelahiran, tingkah laku seksual, aspekaspek kesehatan, kejiwaan dan kemasyarakatan. Atau, dapat pula didefinisikan sebagai pendidikan yang diberikan sebagai upaya pengajaran, penyadaran dan penerangan tentang masalah-masalah seksual, yang diberikan pada anak sejak ia mengerti masalah-masalah yang berhubungan dengan seks, dorongan seksual, dan perkawinan. Atau, pendidikan yang diberikan dalam rangka penerangan tentang anatomi, fisiologi seks manusia, dan bahaya penyimpangan seksual serta penyakit kelamin dan lain-lain akibat perilaku seksual menyimpang.

Tujuannya, mengarahkan dan membimbing seseorang sehingga memahami arti, fungsi, dan tujuan berhubungan seksual sehingga dalam memenuhi kebutuhan seksual dilakukan secara baik, benar dan legal. Harapannya, seseorang tidak terjebak pada perilaku seksual menyimpang. Apalagi akses informasi tentang seks, pornografi dan semacamnya belakangan mudah diperoleh melalui internet, HP, majalah, media massa dan lain sebagainya.

Pada konteks ini, pendidikan seks dapat mencakup dua hal: pertama, sex instruction, yaitu penerangan atau pengajaran mengenai anatomi seperti reproduksi dan semacamnya; dan kedua, education in sexuality yang mencakup bidang etika, moral, fisiologi, ekonomi, dan pengetahuan lainnya yang diperlukan seseorang agar memahami dirinya sendiri sebagai individu yang seharusnya menjaga batasanbatasan seksualitas.

Dalam perspektif pendidikan Islam, pendidikan seks dikaitkan dengan persoalan aqidah dan akhlaq, serta ibadah. Sebagai contoh tentang bagaimana Islam mendeskripsikan pernikahan sebagai solusi untuk memenuhi kebutuhan akan dorongan seksual dan berkasih sayang dengan lawan jenis. Alquran juga mengajarkan bahwa perilaku seksual menyimpang adalah sesuatu yang amat dilarang bahkan diharamkan secara normatif dalam ajaran Islam. Contohnya tentang homo seksual.

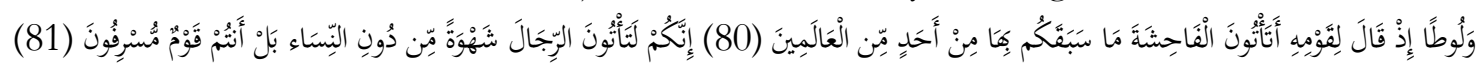
Dan (Kami juga telah mengutus) Luth (kepada kaumnya). (Ingatlah) tatkala dia berkata kepada mereka: "Mengapa kamu mengerjakan perbuatan faahisyah (bomoseksual) itu, yang belum pernah dikerjakan oleh seorangpun (di dunia ini) sebelummu?" Sesunggubnya kamu mendatangi lelaki untuk. melepaskan nafsumu (kepada mereka), bukan kepada wanita, malah kamu ini adalab kaum yang melampani batas (QS al-A'raf: 80-81). 
Tidak hanya itu, pendidikan seksual dalam Islam juga nampak dalam ajaran untuk mengenakan jilbab pada kaum perempuan semata untuk memuliakan dan melindungi kehormatannya. Hal ini sejalan dengan firman Allah dalam al-Ahzab ayat 59.

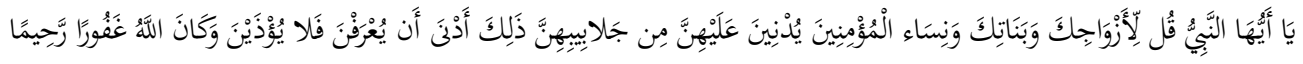

Hai Nabi, katakanlah kepada isteri-isterimu, anak-anak perempuanmu dan isteri-isteri orang mukmin: "Hendaklah mereka mengulurkan jilbabnya ke selurub tubuh mereka". Yang demikian itu supaya mereka lebih mudah untuk dikenal, karena itu mereka tidak diganggu, dan Allah adalah Maha Pengampun lagi Maha Penyayang.

Dalam Islam juga diajarkan tentang bagaimana pentingnya memisahkan tempat tidur antara anak perempuan dan anak laki-laki, terutama saat usianya menginjak 10 tahun. Mengajarkan pula tentang bagaimana pentingnya mereka meminta izin saat memasuki kamar orangtuanya, terutama pada waktuwaktu yang diisyaratkan dalam QS an-Nur ayat 31.

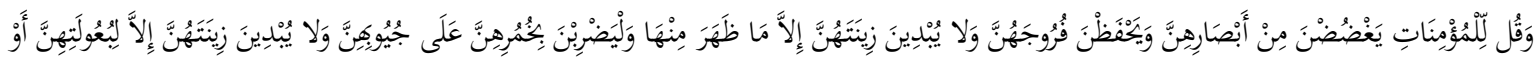

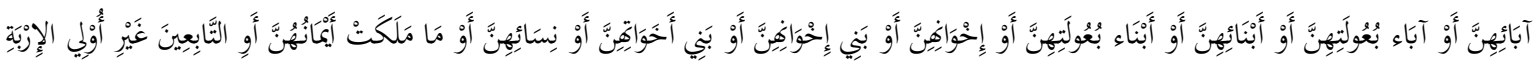

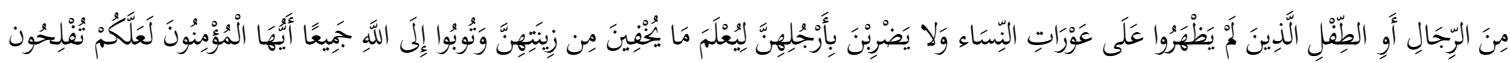

Katakanlah kepada wanita yang beriman: "Hendaklah mereka menahan pandangannya, dan kemaluannya, dan janganlah mereka menampakkan perbiasannya, kecuali yang (biasa) nampak dari padanya, dan hendaklah mereka menutupkan kain kudung ke dadanya, dan janganlah menampakekan perbiasannya kecuali kepada suami mereka, atan ayah mereka, atan ayah suami mereka, atan putera-putera mereka, atan putera-putera suami mereka, atan saudara-sandara laki-laki mereka, atan putera-putera sandara lelaki mereka, atan putera-putera saudara perempuan mereka, atau wanita-wanita islam, atau budak-budak yang mereka miliki, atau pelayan-pelayan lakilaki yang tidak. mempunyai keinginan (terbadap wanita) atau anak-anakyang belum mengerti tentang aurat wanita. dan janganlah mereka memukulkan kakinyua agar diketabui perbiasan yang mereka sembunyikan. dan bertaubatlah kamu sekalian kepada Allah hai orang-orang yang beriman supaya kamu beruntung.

Demikianlah dalam kacamatan psikologi dan pendidikan Islam, penyimpangan seksual dapat diminimalisir sejak dini manakala seseorang mendapatkan bimbingan dan pengarahan sejak dini, termasuk pengetahuan yang di dalamnya menyoal problematika dan wawasan seksualitas. Pendidikan Islam tentang seks pada konteks ini integral dengan pendidikan aqidah dan akhlak dan juga ibadah.

\section{PENUTUP}

Berdasarkan ulasan di atas, bisa disimpulkan bahwa perilaku seksual secara teologis tidak dibenarkan dalam ajaran Islam. Hal ini karena menurut Islam, perilaku seksual menyimpang tidak sejalan dengan fitrah kemanusiaan.Sementara dalam sudut pandang psikologi, perilaku seksual menyimpang dapat muncul karena sebab: libido seksualitas, penundaan usia pernikahan, tabu dan larangan dalam membincangkan problematika seks, kurangnya informasi tentang seks, dan pengaruh pergaulan bebas.

Untuk meminimalisir kemungkinan munculnya perilaku seksual menyimpang, pengetahuan dan wawasan tentang seks dan problematikanya perlu diajarkan sejak dini, terutama agar seorang anak memandang seks kea rah yang positif. Pendidikan tentang seks ini mencakup sex instruction dan education in sexuality. Dalam Islam, pendidikan seks bahkan semestinya dapat integral dengan pendidikan aqidah, 
akhlaq dan juga ibadah. Hal ini bisa dibaca dalam sejumlah ayat Alquran dan teladan Rasulullah Saw yang berkaitan dengan hal tersebut.***

\section{REFRENSI}

Abdullah, "Definisi Penyimpangan Seksual", dalam http://www. diffy. Com / cmm / artikel / definisi. penyimpangan1.html) (Akses 21 September 2016).

Azhar, Ahmad Abu Miqdad. 2006. Pendidikan Seks Bagi Remaja. Yogyakarta: Mitra Pustaka.

Dianawati, Ajen. 2006. Pendidikan Seks Untuk Remaja. Jakarta: Kawan Pustaka.

https://m.tempo.co/read/news/2016/05/17/064771733/kasus-gagang-pacul-usia-enno-farihahternyata-19-tahun (Akses 21 September 2016).

http://regional.liputan6.com/read/2499720/kronologi-kasus-kematian-yuyun-di-tangan-14-abgbengkulu (Akses 21 September 2016).

Ibn Qayyim. 2000. Jangan Dekati Zina. Terj. Tim Darul Haq. Jakarta: Yayasan al-Shafwah.

Junaedi, Didi. 2010. 17+: Seks Menyimpang. Jakarta: Semesta Rakyat Merdeka.

Martiana, Septina "Psikoanalisis (Sigmund Freud)", http: / / septimartiana. blogspot. co. id / 2014 / 01 /psikoanalisis-sigmund.html (akses 28 September 2016).

Nasution, Agus Salim, "Homo Seksual dalam Pandangan Hukum Islam” (Jurnal Ushuluddin, Voume 21, Nomor 1, Januari 2014.

Prastowo, Adi. 2011. Metode Penelitian Kualitatif dalam Perspektif Rancangan Penelitian. Yogyakarta: Arruzz Media.

Rangkuti, Ramlan Yusuf, "Homo Seksual dalam Perspektif Hukum Islam”, Asy-Syir'ah, Volume 46, Nomor 1, Januari-Juni 2012.

Sarwono, Sarlito. 2002. Psikologi Remaja. Jakarta: Raja Grafindo Persada.

Satori, Djaman dan Aan Komariah. 2013. Metodologi Penelitian Kualitatif. Bandung: Alfabeta.

Suyanto, Bagong dan Sutinah. 2006. Metodologi Penelitian Sosial: Berbagai Alternatif Pendekatan. Jakarta: Kencana Prenada Media Group.

Yayasan Penerjemah Alquran. 1980. Alquran dan Terjemahan. Madinah: Qadim al-Haramain al-Syarifain. 